\title{
The Al-Shabaab: Implication of Kenya's Incursion to Somalia on the Kenya-Somalia Relation
}

Dr. Tom Destiny Namwambah*

Kenyatta University, Thika Road, Nairobi City, Kenya

DOI: $10.36347 /$ sjahss.2020.v08i04.003

| Received: 31.03.2020 | Accepted: 07.04.2020 | Published: 08.04.2020

*Corresponding author: Tom Destiny Namwambah

\section{Abstract}

Violent non-state actors (VNSAs) are individuals or groups that are wholly or partly independent of state governments that usually use violence as a means to their objective goal. VNSA's reason for propagating violence is often informed by various factors: self-determination occasioned by suppressive regimes; right to access and control resources; land; religious and cultural ideological beliefs; perennial historical injustices; and push for self-rule among others. VNSAs play a prominent role in nearly every humanitarian and political situation within the international community. The activities of VNSA groups are complex, and if their engagements are conducted across international borders it can impact negatively on the relations and bilateral cooperation between the affected states. Harakat AlShabaab al-Mujahedeen commonly known as Al-Shabaab, officially pronounced in 2006 is a VNSA operating from Somalia. Al-Shabaab has been christened a terrorist group by a number of nations, especially in the western world. I recognize that acts of terrorism are inhuman, barbaric and a threat to global peace, regional harmony and mutual coexistence between nations. Acts of terrorism are often meted on the unsuspecting innocent; they instill fear of insecurity and lead to destruction of property; creates suspicion along religious divides and waters down the cordial interstates relation definitive of the modern global community. Globally, acts of terrorism have been visited on many countries including the United States of America (USA), Germany, Britain, France, Kenya and many others; and such acts have heightened suspicion, tension, clash of interests and led to disharmony between the affected nations and those perceived to sympathize, harbor, host and support acts of terrorism. There is however some disconnect in delineating acts of terrorism from those of liberation movements especially when coercive strategies apply. The thin distinguishing thread between the two organizations has led to blurred and often self-serving interpretations, understanding and definitions by different nations and organizations. In the Eastern part of Africa, the protracted and the intractable assault by Al-Shabaab has been directed more to Kenya than to any other state in the region. Who exactly is the Al-Shabaab - a terrorist organization or a liberation movement? Why does the Al-Shabaab group target Kenya? How has Kenya's incursion into Somalia to pursue the Al-Shabaab impacted on Kenya-Somalia relation? By examining various instances that have characterized the contest between the Al-Shabaab as a non-state actor on the one hand; Kenya's determination to annihilate the Al-Shabaab; and the disquiet among the leadership of Somalia over Kenya's continuous presence in Somalia on the other, this article explores the complexity of the web of tension and its impact on Kenya-Somalia relation.

Keywords: Terrorism, liberation movement, self-determination, incursion, Al-Shabaab, realism, imperialism, international relations.

Copyright @ 2020: This is an open-access article distributed under the terms of the Creative Commons Attribution license which permits unrestricted use, distribution, and reproduction in any medium for non-commercial use (NonCommercial, or CC-BY-NC) provided the original author and source are credited.

\section{INTRODUCTION}

According to the realist theory of International Relations State power is the key and the most vital to nation's interests [1]. This is so because it is only through power that States can defend themselves, whirl through transnational storms and hope to survive. To realists power is understood in a variety of ways: militarily prowess, economic potency, diplomatic maneuvers and ultimately the distribution of coercive material capacity as the determinant of politics in the international arena.

According to Mearsheimer [2], this vision of the world rests on four assumptions: First, the principal goal of every State is its survival- capability to guard itself from external threats, invasion and occupation are the most pressing threats that any State faces. Accordingly, the anarchy of the international system 
compels each States to constantly ensure that they have sufficient power to defend themselves and advance their material interests necessary for survival; secondly, States are rational actors; given the goal of survival, States will always act as best as they can in order to maximize their likelihood of continuing to exist; thirdly, all States possess some military capacity, and no State knows what its neighbours' precisely intend; this is premised on the knowledge that the world is dangerous and uncertain, and discreet in terms of military capacity is weapon in itself for state survival; and fourth, it's the States with most economic clout and, especially, military might that are most decisive and effectively functional in the international domains. In this view, international relations is essentially a story of contest between powers and survival for the fittest. Hegemony, therefore is prima facie to all nations. This vies was uncontestable during the pre-cold war period where actors on the international scene were predominantly states.

In contemporary times however, a new phenomenon in international relations has emerged and it threatens the states' monopoly of power, security and sanctity of nation-states. Actors in international relations are no longer states per se' but also non-state actors. Among those non-state actors is a category of vicious and uncompromising individuals or organizations referred to as violent non-state actors (VNSA), also known as non-state actors. These individuals or groups are either wholly or partly independent of state governments and they often pose threats or use violence to achieve their goals and they include groups such as terrorist organizations (ISIS, AlQaeda, Al-Shabaab etc.), drug cartels, insurgents or freedom fighters and human rights advocacy groups among others [3].

VNSA plays a prominent role of reconfiguring human society be it in social stratification, humanitarian crisis, political configuration or economic proclamation and determination all over the world [4]. According to Phil Williams [5], VNSAs have, in the $21^{\text {st }}$ century become a significant pervasive challenge to nationstates and are catalytic to tension between nations. He further observes that VNSAs often develop out of poor state governance of states, and as such they act to change the status-quo by undermining governance of states, especially those that are democratically unstable $[5,6]$. Whereas some VNSAs oppose governments, others are allied to them and work closely to enhance the government's goals. Some VNSAs may be informally structured and use violence in other ways, such as kidnapping, using improvised explosive devises and killing innocent citizens among other acts. Terrorist groups and to an extent liberation movements fall within this later cluster of the VNSAs, exhibiting almost similar tactics and strategies to influence and instil fear as a way of achieving their objective goal [7].
The prominence of VNSA groups in the contemporary international community is so visible and pronounced to a magnitude of attracting attention from states and umbrella international community organizations such as the United Nations, European Union, and African Union among others. But what exactly are the distinguishing characteristics between liberation movements and terrorist groups as VNSAs? Let me start here.

\section{Liberation Movements: definitions and features}

The word liberation literary means "setting free or releasing from", first used in the English language in the fifteenth century. The term was not widely used in a political sense until the mid-nineteenth century and especially the mid-twentieth century. The temporal and geographic span of such movements as the North and South American wars of independence in the late eighteenth and early nineteenth centuries coupled with series of European nation-building processes of the mid- and late nineteenth century; continuing through the decolonization struggles in Asia and Africa in the mid-twentieth century and beyond pointed a picture of similarities between diverse events occurring across the globe. Accordingly, despite the glaring variation among national liberation movements in terms of the political, historical, socio-cultural factors, and general aims, a common thread cuts across them all: the need to contend and be allowed to run the affairs of the state as to satisfy the vision on which the state is founded; and be free from both friends and foes to undertake nation-building projects that are central as to be visible within the international arena without external meddling.

What exactly causes liberation movements? Why do they arise when and where they do? There are various factors that lead to the emergency of liberation movements. To some degree the need to preserve and assert national or ethnic identity and solidarity are critical factors to the evolution of liberation movements, though on their own cannot satisfy why they emerge. Although the quest for national identity is a critical factor for nationalist consciousness and can trigger massive mobilization, economic and socio-cultural factors are equally critical. The need to ward-off ravenous capitalists scrambling to influence a nation's leadership for their personal interest; marginalization of communities in the allocation and sharing of national resources, enhancement of ethnocentrism - the feeling of one community as superior to others within the same nation; debasement of a peoples' way of life, their history and culture; the arbitrary boundary demarcation caused by the colonial governments that split groups between distinct states; poor governance and skewed development programs are major contributing factors to the emergence of liberation movements in Africa. 
A number of scholars have also argued that liberation movements arise for some similar reasons that lead to the emergence of any other social movements: widespread grievances; preexisting collective identity such as widespread national or ethnic identity; some significant formal or informal organization or socio-religious ties among selfidentified population; a sense of political empowerment or efficacy; and the need to define a peoples' destiny as a unit plus leads to collective consciousness and collective action. In this context, liberation movements initially focuses on very specific grievances and gradually outgrow to address more general grievances as they evolve into movements claiming to represent the aspirations of a national or ethnic group. During and after the transformation of such movements into national or ethnic movements, they typically help spread a sense of national or ethnic identity to growing numbers of people, and thereby becoming the peoples' voice of reason.

On the other hand, some scholars have also proposed specific theories of nationalist or ethnic mobilization as defining the course of liberation movements. These theories tend to focus on the political and social conditions that encourage specifically ethnic or national identities which generate widespread grievances among ethnic and national groups. One of the views in this context mirrors those socially and territorially segregated ethnic groups that come into economic or military competition with one another. It argues that such groups are likely to develop strong ethnic identities and to mobilize in collective self-defense against their antagonists. In such a contest, the wealthier, aggressive and more powerful group may mobilize in reaction to a perceived threat, and the poorer and less powerful group may mobilize so as to improve its own collective interests. A competition of this kind may become so fierce, bloody and even destructive if the two communities are or become more nearly equal and may concomitantly and gradually erode the fiber that glues the state together and lead to intractable and protracted conflict to the extent that the two populations become socially disintegrated with the possibility of cessation.

The political exclusion and domination of particular ethnic groups on the basis of their ethnicity is also likely to encourage ethno-nationalist identities and movements for political emancipation and affirmation. As earlier indicated, the colonial system in Africa strongly encouraged the formation of national identities and liberation movements even among groups that did not previously consider themselves as a cluster or members of the same group. Boundaries during the colonial times were arbitrarily drawn in total disregard of the ethnic composition of the indigenous populations. The demarcation of people did not only create confusion and the urge among the divided groups to unite, but also set the stage for artificial identities which in the long run were recipes for revolts and selfdetermination.

Unlike the tradition understanding of a liberation movement as simply a social movement seeking territorial independence and enhanced cultural and political autonomy within an existing territorial enclave with a defined political governing system, today the term has been extended to refer to other groups determined to seek and free themselves from various forms of domination and discrimination, including the quest for self-determination. National liberation movements have played a critical role in the reshaping of the modern world, especially during the pursuit and agitation to dismantle colonialism in Africa and create nations founded on the aspirations of the indigenous people. Colonial regimes had established systems that abused the rights of the locals, suffocated the right to self-determination, condemned the indigenous people to servitude, expropriated the wealth and arable land from the rightful owners; and used the local jurisdictions as conveyor belts and sources of raw materials to their nations of origin. As a result of the policies and systems of administration adopted by the colonial regimes, the locals lived in a state of perpetuate fear and as Thomas Hobbes would rightly put it, the indigenous peoples lives was continual fear, and danger of violent death; while their lives were solitary, poor, nasty, brutish, and short. So as a result of the division of the globe into nation-states and the disintegration of colonial chains, a number of colonial masters intended to perpetuate their hegemony by imposing some kind of lukewarm leadership of the "independent-becoming" states with a view of continued control and manipulation. For those who believed in the need to have a positive political voice and control over their people could not admit to a system and the leadership brewed, packaged and planted by the same system they fought to get rid of. What followed was a barrage of wars in those states, led and executed by local dissatisfied groups with the aim of achieving the true objective goal of self-rule. And as the western hegemonic syndrome continues to haunt many of the independent African states, the need to eliminate the western domineering syndrome on the local sovereign states will continue to breed new liberation movements. To this end, the fundamental aspects of the modern world cannot be understood without understanding the factors catalytic to liberation movements.

Generally, the strategies executed by liberation movements have generally been shaped by their organizational strength, capacity to sustain themselves, recruitment and training prowess, tactical ingenuity; as well as some aspects of responses from the targeted and affected authorities [8]. Some authorities derive political advantage in the emergency of liberation movements within their jurisdiction and as such extent support or even grant the right to self-administration to such regions as long as the granting authority is certain 
of having dominance of control of resources. This was the case when the bigger Sudan granted the right to selfadministration to South Sudan, Ethiopia to Eritrea, and the Apartheid system to the rule of African majority in South Africa. In some cases, the authorities have been more accommodating to narrowly political movements especially those dominated by economic elites that do pose serious challenge and threats to their economic well-being and their constituents. But on the other hand, authorities have also held a strongly and usually aggressive and violently resist to liberation movements, especially those that represents a threat to their economic interests, and the interest of their allies. As a result of the aggressive hostility meted on them, the liberation movements have ended up adopting more coercive strategies of their own, including forms of armed struggle such as guerrilla warfare and terrorism, the latter strategy being more common in states with massive resources and economic wealth such as mineral or natural resources to which interests are multi-faceted, with developed nations calling shots. But at what point does a liberation movement transform into a terrorist group? Is the Al-Shabaab group a liberation movement or a terrorist group? What is terrorism?

\section{Nature and Characteristics of Terrorism}

Providing a definite definition for terrorism has been accosted with a series of controversies. The word's etymology is however to be traced from Latin, "terrere", meaning "to frighten" and later the French, "terrorisme", which has often been associated with the Regime de la Terreur, or the Reign of Terror advanced by the revolutionary government in France from 1793 to 1794. The Committee of Public Safety agents that enforced the policies of "The Terror" were often referred to as "Terrorists".

The English word "terrorism" was first recorded in English dictionaries in 1798 as meaning "systematic use of terror as a policy". The Oxford English Dictionary still records a definition of terrorism as "Government by intimidation carried out by the party in power in France between 1789 -1794".

The closest Kenya's legal system has come in defining terrorism is to be derived from the Prevention of Terrorism Act, 2012 where the term "terrorist act" is defined as "an act or threat of action which involves the use of violence against a person; endangers the life of a person, other than the person committing the action; creates a serious risk to the health or safety of the public or a section of the public; results in serious damage to property"; and involves the use of firearms or explosives, the release of any dangerous, hazardous, toxic or radioactive substance or microbial or other biological agent or toxin into the environment, interference with electronic systems resulting in the disruption of the provision of communication, financial, transport or other essential services, interference or disruption of the provision of essential or emergency services, prejudicing national security or public safety and are carried out with the aim of:intimidating or causing fear amongst members of the public or a section of the public; or intimidating or compelling the Government or international organization to do, or refrain from any act; or destabilizing the religious, political, constitutional, econ omic or social institutions of a country, or an international organization [9]. The narrative advanced here seems to echo what is common and prevalent to all acts of discontented and disillusioned population seeking to redefine their destiny by off-setting a rotten and insensitive regime bent on suffocating the rights of the people; they are not acts exclusively unique to terrorism as such.

The United States Department of Defense defines terrorism as "the calculated use of unlawful violence or threat of unlawful violence to inculcate fear; intended to coerce or to intimidate governments or societies in the pursuit of goals that are generally political, religious, or ideological." Within this definition, there are three key elements - violence, fear, and intimidation - and each element produces terror in its victims. But this definition also possess some serious challenges: what are lawful and what are unlawful violence and threats? Violence or the threat of it regardless of who perpetuates it is a recipe for fear, panic and creates disharmony to the rhythm of life in human society.

Reading from the above definition, the Federal Bureau of Investigation (FBI), a critical organ of the US hegemony and global superiority defines terrorism as "the unlawful use of force and violence against persons or property to intimidate or coerce a government, the civilian population, or any segment thereof, in furtherance of political or social objectives." To its part, the U.S. Department of State defines terrorism to be "premeditated politically-motivated violence perpetrated against non-combatant targets by subnational groups or clandestine agents, usually intended to influence an audience" (Title 22 Chapter 38 U.S. Code $\S 2656 f)$. The three concurrent definitions are question-begging and seems skewed to serving the hegemonic syndrome characteristic of the United States of America. Our argument follows from the fact that the three definitions fail in context and content to distinguish terrorism from acts of liberation movements that have been pushed from the use of soft power to the application of coercive means.

Before turning back to the above issue, it's important to observe that limitations notwithstanding, there seems to be some salient features characteristic of what today is considered as terrorism, namely:

a) the use of violence or the threat of violence in the pursuit of political, religious, ideological or social objectives; 
b) acts committed by non-state actors or by undercover personnel serving on behalf of their respective governments or interest group;

c) acts reaching more than the immediate target victims and also directed at targets consisting of a larger spectrum of society

d) are both mala prohibita (i.e. crime that is made illegal by government) and mala in se (i.e. crime that is inherently immoral or wrong)

Again, these features takes us back to the question of differentiation between acts of liberation movements and those of terrorist organizations. It seem, in both context that liberation movements, when beleaguered, repressed and viciously contested by an authority and its cohorts cannot disband or surrender but will mature into a formidable resistance group that targets its immediate adversary and her sympathizersthis is what the west christened terrorism, totally failing to adhere to the ancient cautionary wisdom from the native Americans epitomized in the adage- "when you are at the bottom there is no place to go but up".

We also made an observation that in many of the definitions of terrorism, emphasis is laid on the so called "unlawful violence or threat of unlawful violence to inculcate fear". I may not be versed in matters of law but my knowledge compels a degree of skepticism; I have traversed the world and witnessed a number of uprisings, demonstrations and resistance movements, but I am yet to witness any that was gladly welcome by an authority as lawful; provisions in law notwithstanding. It is naïve and abuse to reason to adduce in law what is inadmissible in practice; appearance and reality are not cousins. Back to my questions; is Al-Shabaab a terrorist group or a liberation movement?

Earlier we made the point that in international politics the law serves the superpowers, sustains the hegemony and superimposes their superiority over weak and developing states. This observation is supported by the realist theory of international relations which asserts that State power is the key and the most essential to nation's interests; and it is only through power that States can defend themselves, whirl through transnational storms and hope to survive [1]. State power is understood in and manifests itself through a variety of ways: militarily prowess, economic potency, diplomatic maneuvers and ultimately the distribution of coercive material capacity as the determinant of politics in the international arena.

As a result of the above, state survival is anchored on four assumptions: i) the prima facie goal of every State is its own survival: to guard itself from external threats; invasion and occupation being the most pressing threats. Accordingly, the anarchic nature of the international system compels each States to constantly ensure that they have sufficient power to defend themselves and advance their material interests necessary for survival; ii) states are rational actors; given the goal of survival, each state will always act as best as it can in order to maximize its likelihood of continuing to exist; iii) each state possess some military capacity, and no other state knows what its neighbour precisely intend; this is premised on the knowledge that the world is dangerous and uncertain, hence nondisclosure of military capacity is weapon in itself for state survival; and iv) it's the state(s) with most economic clout and, especially, military might and economic prowess that are most decisive and effectively functional in the international domains [2]. In line with this view, international relation is basically a story of contest between powers and arena of survival for the fittest; hegemony being the fundamental pursued principle by all nations. To this end, International law is plausible if it serves to maintain the status-quo and the hegemony of the world superpowers. As unfortunate as this may seem to be, this absurdity defines the world order today and it has for some time now been a central recipe to upheavals, confrontations and instability in many nations. Is the Al-Shabaab informed by the reality definitive of international politics?

\section{The Origin and Evolution of the Al-Shabaab Organization}

Al-Shabaab (Harakat al-Shabaab alMujahideen) is an Arabic term which literally means "the youth". Following the dethronement of President Mohammed Siad Barre in 1991, an insurgent group comprising of religiously intolerant armed militia young men was officially pronounced in 2006 as an armed wing of the Islamic Courts Union that ruled most of the southern and central parts of Somalia from the capital Mogadishu. The initial aim for Al-Shabaab was to fight and drive out Ethiopian troops after the overthrow of the Islamic Courts Union administration on the one hand; and the African Union and their western countries allies' intervention in Somalia on the other. The group's mission was also to ensure that no Western-backed government survives in Somalia and they pursued the need to impose a strict interpretation of Islamic law.

There are also historical factors that informed the emergency of Al-Shabaab revolutionary movement. In their work, Arce and Sandler [10] observes that besides Somalia having been a Muslim Country for close to a thousand years, the Al-Shabaab stemmed from a Salafi-Wahhabi strand of Sunni Islam and as such, the group sees aspects of Sufi worship as heretical, a factor that has caused tensions with a number of Somali communities and leaders. Whereas Sufis content with the current geographical boundaries of the current Somalia State, the Al-Shabaab rejects the nation-state borders of modern Somalia, believing that the frontiers drawn by the British, seceding a section of their territory to Kenya was erroneous and amounted to the annexation of part of their territory illegally. As a result, some section of the Al-Shabaab embrace the idea 
of a Greater Somalia and aims to establish an Islamic government in the country with all their kin that were annexed to Kenya. As a means to awakening nationalist and patriotic sentiments amongst their "SomaliKenyan" kin, radical Islamic themes became more influential in Somalia following the return from Afghanistan of veterans of the war against Russia in the 1980s, as well as increased access to religious and university scholarships in Sudan and Saudi Arabia for young Somali men [10].

From the very inception of the Union of Islamic Courts (UIC), their efforts to effective governance of Somalia were thwarted by the Ethiopian troops which invaded Somalia in December 2006 and banished them out of Mogadishu. What followed thereafter was an array of condemnations, incessant attacks, atrocities and undeterred efforts to annihilate the UIC and its new born - the Al-Shabaab movement. In so doing, the international community's efforts were premised on the belief that the panacea to a unitary democratic government in Somalia was only possible in the absence of UIC and the militant Al-Shabaab group. And in order to win the international support. Ethiopia, African Union and their western allies dubbed AlShabaab liberation movement a dangerous terrorist organization that must be annihilated at all cost.

\section{Kenya's incursion to Somalia}

Of nations in the eastern and Horn of Africa Kenya has been the worst affected by the vicious and atrocious attacks by the Al-Shabaab militants. (Anderson, 2015; SAST, November 15, 2017). As a response to the frequent attacks and kidnaps in Kenya by the Al-Shabaab operatives prior to 2011, on October $16^{\text {th }} 2011$ Kenya dispatched some 2,000 troops across the border into Somalia to pursue what the then Kenya's internal security Minister Prof. George Saitoti, termed "criminals from Somalia bent on destabilizing Kenya" (Daily Nation, 17/10/2011). To the best of the government reporting, Kenya government troops invaded its immediate neighbor, contrary to the provisions of international law on two grounds: i) to pursue criminals from Somalia bent on perpetuating crimes in Kenya; ii) to secure Kenya's northern frontier and; iii) to create a buffer zone within Somalia in order to curtail the Al-Shabaab incursion in Kenya [11].

Following Kenya's invasion of Somalia, a coordinated operation between the Somali military and the Kenya military dubbed Operation Linda Nchi began series of attacks against the Al-Shabaab insurgents in southern Somalia in October 2011. In early June 2012, Kenyan troops were formally integrated into AMISOM, a regional military operation established presumably to create sanity in the region and assist in stamping out the Al-Shabaab activities, pave way for the reestablishment of a legitimate government and assist in the return to the rule of law in Somalia. By September 2012, the Somali National Army and allied Kenyan African Union forces and Raskamboni militia had managed to capture AlShabaab's last major stronghold, the southern port of Kismayo, during the Battle of Kismayo (The Guardian, Retrieved 28 September 2012) [12].

As plausible as the reasons for Kenya's retaliatory push and pursuit of Al-Shabaab into Somalia my sound, they were sooner, later in 2012 contradicted by the government spokesperson Dr. Alfred Mutua who alleged that the incursion was not necessarily occasioned by the need to pursue the alleged kidnappers across the border, and that kidnapping was a guise to launch a plan that had "been perpetuated for a while" [13]. It seems that besides the onslaught by the AlShabaab militants in Kenya, there are some unfinished businesses: political, social and economic which over time have warmed up tension between Kenya and Somalia.

Further, Kenya government communique to the UN Security Council seems plausible; that the intervention was "a remedial and pre-emptive action" to the Al-Shabaab incursion to Kenya; and that the said incursion was putting Kenya's interests at stake and therefore there was need to secure, protect and preserve the integrity of the nation by securing its borders and guaranteeing security and efficacy of the national economy; secure and guarantee security to the nation. Beyond this effort however, the escalation of the incursion beyond just securing the northern border and creating a buffer zone to including the capture of the lucrative port of Kismayo, dismantling the Al-Shabaab militants and stabilising the Somalia government paints a different picture of Kenya's interests not only in Somalia but also in the Eastern Africa region. And if Kenya's expansion mission in Somalia is informed by Kenya's believe that instability in Somalia is a big threat to the prosperity of region then there is need for other nations in the region to read from the same script and walk the same talk [14].

Kenya's invasion of Somalia also came at a time when the global war on terrorism was heightening. As a member of the international community and for purposes of visibility on the international arena it is logical that Kenya wanted not only to be visible but also to express solidarity in the counter-terrorism blitz. Beyond this quest, it has also been argued, that since independence Kenya's military forces only specialized in accumulation of arsenals without combat encounter on the battlefield. Architects of this school argue that in the Al-Shabaab push-back created an experimental field for harnessing and accumulating combat experience. As to whether this is logically substantive or not, we are of the opinion that subjecting the lives of Kenyans and resources to an experimental pendulum is both unwarranted, naïve and at most unreasonable; it's cost in futility. 
The other argument in support of Kenya's pursuit of the Al-Shabaab into Somalia is that the activities of Al-Shabaab in Kenya were negatively affecting the tourist industry especially in parts of the coastal region such as Lamu, Malindi and Mombasa. Many western countries had started issuing travel alerts to their citizen to be wary of visiting Kenya. This state of insecurity was a big threat to the economic wellbeing of the regions affected and the nation. To cushion its economic interests and win confidence of the international community the Kenya government found it prudent to lethally confront the Al-Shabaab group.

Kenya has been a host to thousands of refugees from Somalia. Many of these refugees are runaways due to the ravaging wars, famine, and lack of basic livelihood essentials. The hostile claws of draught makes the lives of the pastoralist communities in the southern part of Somalia unbearable. Kenya believes that the continuous and ever-increasing number of refugees from Somalia can only be tamed by the establishment of a stable, people-driven and responsible government in Somalia; and is convinced that this cannot be realized in the presence of a hostile, tactical and inhuman militia movement such as the Al-Shabaab.

Personal economic and political interests of some well-connected politicians and military officers from the region, especially the Ogedeni Somali community members; the Jubaland political elites and Kenya's interest in the natural resources in Somalia are among some of the reasons that have kept Kenya into Somalia beyond its initial aim of securing its national border and creating a buffer-zone between the two nations. The need to reclaim its image in the international community and attract foreign investment as a beacon of peace nation in the region is yet another motivating factor to Kenya's continued stay in and onslaught on the Al-Shabaab in Somalia

\section{Why Al-Shabaab target Kenya}

In the entire Eastern Africa region Kenya has been the prime target and recipient of the Al-Shabaab's noxious atrocities. Although some scholars and politicians attribute this to Kenya's proximity to Somalia, its continuous attacks cannot be explained strictly by geography alone. Although Kenya's porous and ill-guarded borders do make it easier for the militia to infiltrate, Ethiopia, Eritrea and Djibouti too have borders with Somalia; Ethiopia having even a much longer border with Somalia than Kenya but not as much targeted as Kenya.

Since October 2011 many attacks have been meted on Kenya, and the Al-Shabaab has claimed responsibility. Among these attacks are: the Machakos bus terminus attack of October 2011 in which five people lost their lives; the attack on a Catholic Church in Garissa that killed seventeen (17) worshipper of July 2012, the attack on a Nairobi bound passenger bus near
Madera killing 28 non-Muslim passengers of November 2014; the killing of 36 non-Muslim quarry workers in Mandera near the border with Somalia of December 2014; the attack on University of Garissa killing over 150 students of April 2015; the attack on Westgate Mall in Westlands District of Nairobi killing more than 70 people of September, 2013; the DusitD2 Complex attack in the Westland District of the capital city Nairobi of January 2019 killing over 21 people; the attack on the joint Kenya-US military base at Manda in Lamu County of January 2020 in which more than four were killed; the $6^{\text {th }}$ January 2020 attack at Kamuthe Primary School Garissa County that claimed the lives of three innocent teachers, and at Saretho Boarding Primary School Dadaab of $7^{\text {th }}$ January 2020 in which four innocent school children were killed are just but some of the gruesome and inhuman acts that Kenya has witnessed at the hands of the Al-Shabaab group. It's evident that the timing, frequency and target choice for the Al-Shabaab is both increasing and being diversified.

Some of the critical factors that cause revolts within or between nations is often the scramble for resources and land; need to assert common identity; or urge to stamp authority of a solid political ideology, especially when the ideology is divine derived. If at the heart of the Al-Shabaab formation was the need to reclaim their ancestral land believed to have ben annexed to Kenya by the British colonial regime then there is more in store not only between Kenya as a State and Al-Shabaab as a non-state actor; but also with the Federal State of Somalia. Often, unsettled historical injustices are difficult to circumvent by mere cosmetic diplomatic gymnastics. If the reclamation of NFD is at the core of Al-Shabaab onslaught then Kenya is yet to see more of the Al-Shabaab venomous acts which might attract sympathy from the Federal Republic of Somalia. If the Al-Shabaab quest is to defend its territorial integrity, and safeguard the wealth of the Somali people and the sanctity of Somalia nation, will we be justified to pronounce it a terrorist organization or a liberation movement? These are troubling observations that might be needing a genuine answer soon or later from the international community.

The presence of the Kenyan-Somali community in Kenya with their kin in Somalia, and the fact that marginalization of the community has been voiced by both the locals and their leadership creates an angle for sympathy from their kin in Somalia - to advance their goal and agitation for recognition, inclusion and support. This is a factor that may explain the ease in recruitment and participation in the AlShabaab activities by a number of Kenyan-Somalis youth.

Kenya is a darling and an ally to a number of western nations, including USA, Britain, German and others. The presence of these nations in Somalia is one of the cause of Al-Shabaab's formation - to eject them 
or any government supported by them from their land. The availability of massive resources in Somalia, especially oil wells has attracted competition from the western nations to which Kenya provides the entry and exit path. To the Al-Shabaab, an attack on Kenya is an attack and humiliation to the capitalist nations ravenously coveting the wealth of their nation.

The Al-Shabaab's focus on Kenya is also based on both logical and opportunistic reasons. Kenya is based on geographical proximity to Al-Shabaab's bases in southern Somalia; this fact, reinforced by other variables that play into Al-Shabaab's general modus operandi may provide some reasons beyond what is known today as major causal factor. The need for recruitment grounds, training facilities, access to supplies such as foodstuff and even the fact that the Muslim inhabitants are an easy prey on grounds of margination and common religious doctrines makes Kenya a fertile ground

Kenya is also one of sub-Saharan Africa's most important states and East Africa's hub. The strategic location of Kenya as a gateway to the nations in the region accords it international visibility and status more than any nation in the region; a factor that may easily entice the Al-Shabaab to make conscious decisions and efforts to attack it. Attacking targets in Kenya, particularly in Nairobi or on the coast, guarantees Al-Shabaab a level of international coverage that a similar attack in Ethiopia would not.

And more importantly, although Kenya's invasion of Somalia was undertaken for understandable reasons, its decision was contested by her allies and friends, especially the USA and even the neighbor Ethiopia. A number of Somali nationalists and sympathizers to the Al-Shabaab saw the incursion as an insult and assault to the sovereignty and sanctity of Somalia nation. Various reports emerging from successive Somalia interim government regimes have accused Kenya of plundering the economy of Somalia by smuggling sugar, charcoal and other commodities, thus affecting the economy of their nation [15]. The Kenya government and its allies in AMISOM, together with the presence of USA force are also seen as external factor interfering with the internal political reordering of the state of Somalia [16]. Further, the Somalia government now feels that Kenya's attempt to prevent Al-Shabaab from establishing itself on the Kenya border has become a mission overstayed which is causing concern among the leadership of Somalia. And more importantly, the spirited effort by the Al-Shabaab and the majority of the Somalia leadership's determination to rid their nation of foreign influence and interference and have the liberty to impose strict form of Islamic governance in the country is a common motivating factor between the government and the AlShabaab.

\section{Tyranny of Proximity}

Despite Kenya's foreign policy stressing the principle of pursuing peaceful coexistence with her neighbors, Kenya Foreign Policy 2014; the incessant disruption of the relatively calm, stable and peace within its borders propagated by the Al-Shabaab group pushed the nation to retaliate in diverse ways. To date, the Kenya nation continues to reel from the devastation and debris of such attack that have led to a slow-down in the nation's economic performance, scared away potential investors, brought agony and grief to many local and foreign families, and watered down the confidence in the bilateral relation between Kenya and Somalia. The state of insecurity occasioned by the activities of Al-Shabaab in Somalia has led to an influx of refugees to Kenya, resulting in very serious state security challenges [17]. Further, blanket condemnation and unwarranted profiling of the ethnic KenyanSomalis as sympathizers of the Al-Shabaab group and the subsequent high-handed treatment of them by security institutions in Kenya has only served to exasperate the community and further complicate the fight against the Al-Shabaab (Star Tribune, Feb. 24, 2009).

The protracted tension simmering between Kenya and Somalia over maritime borders is also a major concern that can trigger vicious and atrocious onslaught by the Al-Shabaab group on Kenya. In a case filed before the International Court of Justice (ICJ) on August 2014, Somalia sued Kenya arguing that the border between the two neighboring countries should be extended South of Kiunga and not eastwards as it currently is. The bone of contest between the two states is an approximately 100,000 square kilometers that forms a triangle east of the Kenyan coast. The said case took a new twist in favour of Somalia following a ruling by the International Court of Justice (ICJ) that allowed Mogadishu to file a response to a case in which it has sued Kenya. And although Kenya's counter argument has been that any move to adjust the border line could precipitate a border dispute with Tanzania, the court has stood its ground, further heightening the tension between the two states. The case is seen to be propelled by potential oil deposits in the contested region which Somalia in its case argues that Kenya would exploit Somalia's resources should it win the case (MENAFN Som Tribune, October 2019).

In response to this truce, Kenya deployed its military forces to the contested region in 2019, arguing that failure to secure the region will encourage the AlShabaab encroachment and further escalate the contest over the disputed region. The proximity of Kenya to Somalia seems not to be the really bone of contention, but rather the resources available in the region which, not only Kenya is covet but also her western partners such as USA, UK, Israel and their other associates within NATO. To this course, Kenya and her allies are determined to diminish two factors: i) the possibility of 
Somalia forging close ties with Eastern Europe and the Arab world on the one hand; and ii) Islam taking root as the insignia of Somalia political orientation.

The above factors, coupled with the continuous attacks on Kenya by the Al-Shabaab are both worrying and possibly, a destabilizing factor to Kenya -Somalia mutual cooperation and relation. Given some disquiet among some of the Somalis people and the leadership that Kenya's incursion in Somalia has been overstayed and that the sovereignty of their state is abused creates a complex web in terms of the bilateral relations between the two states.

These revelations together with the recent unauthorized secret visit to the FRS President Formajo by Kenyan legislators who on returned declined to discuss the content and subject of their visit; followed by the military fire exchange between the FRS forces and those of the State of Jubaland that almost spilled into Kenya are indicators of a relation gone sour. In the military standoff the President of Jubaland was accused of being an accomplished of a mutiny prison escapee that had either been given refuge in Jubaland or in one of the northern frontier towns of Kenya.

Finally, there also seems to be a strong arm of the significant others who may be finding Kenya's strategic location ideal in pursuit of their own interests in Somalia and the eastern Africa region. For example, the US has showed interest in Somalia ever since the 1970s. By early 1993 Somalia had boldly risen against US and its allied western forces manipulation and imperialism; and the presence of the UN forces in their nation. Both the UN forces and the US suffered a sounding defeat that drove them out of Somalia in 1994. To this end, it seems possible that the current development and the unfolding, both in regard to Kenya's invasion of Somalia to pursue the Al-Shabaab on the one hand and the consequences that accrue from thence: the Al-Shabaab's heightened incursion into Kenya and the strained relations between Somalia and Kenya; and the consequences of the web of foray in Eastern Africa region has to be viewed from the lens of US economic, strategic and imperialist (hegemony) interest in partnership with her NATO allies and Israel. And in recent years the new finding of oil and natural gas along the coastal strip of East Africa are of incontestable interest in the region by the capitalist western powers but at a painful cost to Kenya-Somalia relation [18]. The presence of US armadas and the European Union warships in the Gulf of Aden off the coast of Somalia guised as a watch-tower and fight against piracy for years now attests to the predatory nature of the west: to selfishly guard what they consider a gateway to their interests in Somalia and the Eastern Africa region in general [19].

Israel on the other hand has enormous vested economic interests in Kenya which they would wish to extend to Somalia and other countries in the region; tourist hotels and other businesses including Westgate Shopping Mall are owned by Israeli citizens. The insecurity threat to Kenya therefore threatens the investments and general interests of these nations. Within the web of these significant other Kenya finds itself in the muddle - to purge up with the external west and sacrifice its good and cordial neighbourliness with Somalia and loose the external financial, technological and military support from the west by pursuing good neighbourliness with Somalia. And in this scenario Kenya has chosen the former. The consequence is that Al-Shabaab will stay much longer and Kenya cannot dream of withdrawing its forces from Somalia any time sooner. The repercussion is anyone's guess.

\section{CONCLUSION}

The colonial legacy in Africa left very little to be proud of. The demarcation of nation-state boundaries at the time when the shackles of colonialism and imperialism were being dismantled was totally blind to the history and common roots of many of the indigenous people, causing unnecessary tension resulting from authenticity, jurisdictions and identity. Prior to this confusion, colonial administrations had successful managed to divide the locals along lipstick favours and through pitting one community against another as a means to defusing resistance and containing rebellions. The division and annexation of part of territories that were previously seen as belonging to particular regions, and whose historical identity was manifest through commonality of identity - culture, language and even religion became a recipe for violence and rebellion in many regions of Africa.

The emergency of VNSAs in Africa, especially those that were politically instigated in regions opposed to US hegemonic syndrome and western manipulative maneuvers were not treated softly. The anger among such movements which were bent on reaffirming their right to self-governance and self-determination soon blossomed into organizations that saw it fitting to extend their quest at home to avenging on their adversaries abroad. And where justification to their cause found accommodation in some religious dogma, their vengeance was scaled even mush higher; the result being resistance movements with a global outlook. In order to marshal the solidarity of the international community and safeguard the interests of the capitalists those liberation movements were christened terrorist organizations. This explains the absence of a concrete definition of terrorism save for the self-serving and rationally skewed assertions.

\section{REFERENCES}

1. Waltz KN. Realism and international politics. Routledge; 2008.

2. Mearsheimer JJ. The Perils: Contemporary Realism and International Security. Cambridge, MA: MIT Press. 1995. 
3. Bartolomei F, Wendling F, Regis J, Gavaret M, Guye M, Chauvel P. Pre-ictal synchronicity in limbic networks of mesial temporal lobe epilepsy. Epilepsy research. 2004 Sep 1;61(1-3):89-104.

4. Thomas TS, Kiser SD, Casebeer WD. Warlords rising: Confronting violent non-state actors. Lexington Books; 2005 Aug 9.

5. Williams P. Violent non-state actors and national and international security. International Relations and Security Network. 2008 Nov;25.

6. Andersen DR. Foreign Policy, Decision-Making and Violent Non-State Actors. International Studies; 1994;38(1).

7. Hilderbrand RC. Dumbarton Oaks: The Origins of the United Nations and the Search for Postwar Security. UNC Press. 2001.

8. Irvin JE, Bowers CA, Dunn ME, Wang MC. Efficacy of relapse prevention: a meta-analytic review. Journal of consulting and clinical psychology. 1999 Aug;67(4):563.

9. Crenshaw M. The psychology of terrorism: An agenda for the 21 st century. Political psychology. 2000 Jun;21(2):405-20.

10. Arce DG, Sandler T. Fitting in: Group effects and the evolution of fundamentalism. Journal of Policy Modeling. 2009 Sep 1;31(5):739-57.

11. Downie R. The state of public health in south Sudan: critical condition. CSIS; 2012.

12. Chonghaile CN. "Kenyan troops launch beach assault on Somali city of Kismayo". The Guardian. 2012. Retrieved 28 September 2012.
13. Wafula C. "MPs accuse State of using undue force". Daily Nation. 2012.

14. Duncan RE, Bertholf RJ, Gelpi A. The Letters of Robert Duncan and Denise Levertov. Stanford University Press; 2004.

15. Plaut B, Roughgarde T. Almost envy-freeness with general valuations. InProceedings of the Twenty-Ninth Annual ACM-SIAM Symposium on Discrete Algorithms 2018 (pp. 2584-2603). Society for Industrial and Applied Mathematics.

16. Cannon CP, Bhatt DL, Oldgren J, Lip GY, Ellis SG, Kimura T, Maeng M, Merkely B, Zeymer U, Gropper S, Nordaby M. Dual antithrombotic therapy with dabigatran after PCI in atrial fibrillation. New England Journal of Medicine. 2017 Oct 19;377(16):1513-24.

17. Raghavan D, McAlister HA, Henry TJ, Latham DW, Marcy GW, Mason BD, Gies DR, White RJ, Theo A. A survey of stellar families: multiplicity of solar-type stars. The Astrophysical Journal Supplement Series. 2010 Aug 13;190(1):1.

18. Buyon L, Slaven R, Emerson PM, King J, Debrah O, Aboe A, Ruiz-Tiben E, Callahan EK. Achieving the endgame: Integrated NTD case searches. PLoS neglected tropical diseases. 2018 Dec 20;12(12):e0006623.

19. Kurth A, Kuo I, Peterson J, Azikiwe N, Bazerman L, Cates A, Beckwith CG. Information and communication technology to link criminal justice reentrants to HIV care in the community. AIDS research and treatment. 2013;2013. 